\title{
PENGENDALIAN Vibrio harveyi SECARA BIOLOGIS PADA LARVA UDANG WINDU (Penaeus monodon): I. ISOLASI BAKTERI PENGHAMBAT
}

\author{
Des Roza*), Zafran ${ }^{*}$, Imam Taufik ${ }^{*}$, dan Moral Abadi Girsang ${ }^{* *}$
}

\begin{abstract}
ABSTRAK
Vibrio harveyi merupakan ancaman serius pada usaha perbenihan udang windu (Penaeus monodon) yang menyebabkan kematian massal larva. Cara umum untuk pengendalian penyakit ini biasanya dengan penggunaan bahan kimia maupun antibiotik tetapi kurang efektif karena tingkat keberhasilannya masih sangat rendah. Penggunaan jenis bakteri nonpatogen yang hidup pada lingkungan budidaya pantai dan dapat menekan perkembangan $V$. harveyi penyebab penyakit kunang-kunang pada budidaya udang windu ( $P$. monodon) mungkin merupakan salah satu cara penanggulangan secara biologis yang aman.

Penelitian dilakukan di Loka Penelitian Perikanan Pantai Gondol, Bali dari November 1994 sampai Februari 1995. Dari hasil pengambilan contoh dari berbagai sumber, di antaranya dari air laut, air pemeliharaan larva udang windu, dan udang telah diisolasi 125 isolat bakteri penghambat. Isolat bakteri bercahaya $V$. harveyi diisolasi dari air pemeliharaan larva udang windu di panti benih komersial. Terhadap semua isolat bakteri dilakukan uji daya hambat dalam menekan perkembangbiakan $V$. harveyi pada media Marine Agar (MA). Tiga isolat (GSB-95030, GSB-95033 dan GSB-95040) mampu menghambat perkembangbiakan $V$. harveyi, dan dari tingkat patogenisitasnya terhadap larva udang windu ternyata sampai kepadatan $10^{8} \mathrm{cfu} / \mathrm{mL}$ tidak mematikan larva udang windu stadia zoea-1. Isolat bakteri tersebut digunakan sebagai kontrol biologi dalam air pemeliharaan larva dan mampu menekan pertumbuhan bakteri $V$. harveyi sehingga berada pada kondisi aman (lebih kecil dari $8,35 \times 10^{4} \mathrm{cfu} / \mathrm{mL}$ ) dan memberikan sintasan larva udang yang lebih tinggi dibanding kontrol.
\end{abstract}

\section{ABSTRACT: Biocontrol of Vibrio harveyi in Penaeus monodon larvae rearing: \\ I. Isolation of inhibiting bacteria. By : Des Roza, Zafran, Imam Taufik, and Moral Abadi Girsang.}

Vibrio harveyi infection is one of the serious problems in larval rearing of Penaeus monodon causing mass mortality of larvae. Control of this disease is usually done by using chemicals or antibiotics but not so effective. The use of non pathogenic bacteria living in the coastal aquaculture environment to inhibit the development of luminescent bacteria $\mathrm{V}$. harveyi could be an effective and safe method in preventing the outbreak of luminescent disease in shrimp culture.

This experiment was performed in Gondol Research Station for Coastal Fisheries, Bali from November 1994 to February 1995. A hundred and twenty five isolates of bacteria were isolated from sea water, pond water, rearing water of larvae and adult shrimps. Isolates of $\mathrm{V}$. harveyi were obtained from larvae rearing water of $\mathrm{P}$. monodon at private hatcheries. A series of inhibitory tests of 125 isolates on the growth of $\mathrm{V}$. harveyi on MA medium were carried out. Results of these tests indicated that isolates GSB-95030, GSB-95033, and GSB-95040 were effective in inhibiting the growth of $\mathrm{V}$. harveyi. Pathogenicity test of the isolates on larvae zoea-1 stage, indicated these isolates did not cause mortality of the larvae at a density of $10^{8} \mathrm{cfu} / \mathrm{mL}$. The application of these non pathogenic isolates into larval rearing tanks proved to be effective in supressing the population of pathogenic V. harveyi until the level of less than $8.35 \times 10^{4} \mathrm{cfu} / \mathrm{mL}$, resulting high survival rate of shrimp larvae.

KEYWORDS: biocontrol, Penaeus monodon, Vibrio harveyi.

*) Peneliti pada Loka Penelitian Perikanan Pantai Gondol - Bali

${ }^{\star *}$ Peneliti pada Balai Pengkajian Teknologi Pertanian Sumatera Utara 


\section{PENDAHULUAN}

Kendala utama yang dihadapi panti benih dalam memproduksi benih udang windu (Penaeus monodon) adalah terjadinya serangan penyakit pada stadia larva. Salah satu penyakit yang terkenal adalah penyakit kunang-kunang atau "luminescent vibriosis" (Lightner et al., 1990). Larva yang terinfeksi pada tingkat parah terlihat bercahaya pada kondisi gelap dan penyebabnya telah diidentifikasi sebagai $V$. harveyi (LavillaPitogo et al., 1992; Zafran \& Roza, 1993; Karunasagar et al., 1994). Selain menyebabkan kunang-kunang, $V$. harveyi juga dapat menyebabkan bercak merah pada dasar bak pemeliharaan larva (Lavilla-Pitogo et al., 1992; Roza et al., 1997).

Cara yang ditempuh oleh pengelola panti benih di Indonesia, khususnya di Jawa Timur dan Bali dalam mengatasi infeksi Vibrio spp. terutama $V$. harveyi adalah dengan menggunakan obat-obatan atau antibiotik. Tingkat keberhasilannya sangat bervariasi menurut lokasi dan waktu, bahkan penggunaan antibiotik secara berkelanjutan dan tidak terkontrol dapat menimbulkan resistensi bakteri terhadap obatobatan tersebut (Baticados \& Paclibare, 1992; Roza, 1993). Untuk itu perlu dicari metode lain yang lebih praktis, murah, aman dan efektif serta berwawasan lingkungan untuk mengendalikan populasi $V$. harveyi sampai batas aman. Menurut Zafran \& Roza (1993) V. harveyi akan bersifat patogen bagi larva udang windu apabila kepadatannya dalam air pemeliharaan mencapai $8,35 \mathrm{x}$ $10^{4} \mathrm{cfu} / \mathrm{mL}$. Upaya pengendalian lain misalnya dengan manipulasi lingkungan (Lavilla-Pitogo et al., 1992) atau secara kontrol biologis (Maeda, 1989; Maeda et al., 1992) menggunakan fitoplankton yang bersifat bakterisida atau dengan bakteri sebagai musuh alaminya (Maeda, 1994; Roza, 1995).

Penelitian ini bertujuan untuk mendapatkan bakteri dari lingkungan alami tempat hidup udang windu yang mempunyai kemampuan untuk menekan perkembangan $V$. harveyi. Diharapkan pengisolasian bakteri yang mempunyai kemampuan tersebut tetap tidak bersifat patogen terhadap larva udang windu. Pemanfaatan bakteri tersebut dapat dijadikan alternatif untuk menekan kepadatan $V$. harveyi dalam air pemeliharaan larva sehingga berada pada batas aman dan meningkatkan sintasan larva udang windu (P. monodon).

\section{BAHAN DAN METODE}

\section{Isolasi}

\section{a. Isolat Bakteri Penghambat}

Isolat bakteri penghambat diisolasi dari berbagai sumber yakni dari air laut, air tambak, air pemeliharaan larva pada panti benih, dan dari saluran pencernaan serta insang udang. Isolasi dilakukan menggunakan media MA (Marine Agar) dan TCBSA (Thiosulphate Citrate Bile Salt Sucrose Agar). Semua isolat dimurnikan dan dipelihara pada media MA pada suhu $27^{\circ} \mathrm{C}$, untuk diidentifikasi berpedoman kepada Baumann et al. (1984)

\section{b. Isolat Vibrio harveyi}

$V$. harveyi yang digunakan dalam penelitian ini diisolasi dari air pemeliharaan larva pada panti benih udang windu komersial di Banyuwangi, Jawa Timur dengan cara pengambilan contoh air. Kemudian dikultur pada media TCBSA sebanyak $0,1 \mathrm{~mL}$ dan diinkubasi pada suhu $27^{\circ} \mathrm{C}$ selama 8-12 jam. Terhadap koloni yang berwarna hijau dan bercahaya dalam kondisi gelap dilakukan pemurnian pada media MA.

\section{Uji Daya Hambat Isolat Bakteri terhadap $V$. harveyi pada Media MA}

Semua isolat murni yang diperoleh diuji kemampuannya dalam menghambat pertumbuhan $V$. harveyi pada media MA dengan berpedoman pada Maeda (1994). Isolat bakteri uji digoreskan masing-masing dua kali sepanjang $4 \mathrm{~cm}$ pada tiga plat MA untuk di pra-inkubasikan masing-masing selama 24,72 dan 144 jam pada suhu $27^{\circ} \mathrm{C}$. Setelah masa pra-inkubasi, di antara kedua goresan isolat uji digoreskan $V$. harveyi dengan jarak $1,5 \mathrm{~cm}$ dan panjang goresan $2 \mathrm{~cm}$. Pengamatan dilakukan setelah dua minggu terhadap kemampuan isolat uji untuk menghambat perkembangan $V$. harveyi. Isolat dinyatakan mempunyai daya hambat apabila lebar $V$. harveyi yang tumbuh tidak lebih dari $0,5 \mathrm{~cm}$, dibanding. kan bila digores tunggal (kontrol). 
Uji Patogenisitas Isolat Bakteri Penghambat terhadap Larva Udang Windu (P. monodon)

Terhadap isolat bakteri penghambat terbaik dalam menekan perkembangan $V$. harveyi dilakukan uji patogenisitas terhadap larva udang windu. Ke dalam 15 botol kaca yang berisi dua liter air laut steril (disterilkan dengan otoklaf pada suhu $121^{\circ} \mathrm{C}$ selama 15 menit) dimasukkan hewan uji yakni 100 ekor larva udang windu stadia zoea-1 yang diperoleh dari panti benih komersial di Banyuwangi, Jawa Timur. Rancangan yang digunakan dalam penelitian ini adalah acak lengkap dengan perlakuan tiga isolat bakteri yang memberikan penghambatan tertinggi, masing-masing perlakuan dengan tiga ulangan. Ke dalam botol kaca yang dipilih secara acak diinokulasikan suspensi isolat bakteri penghambat pada kepadatan masing-masing $10^{5}, 10^{6}$, $10^{7}$ dan $10^{8} \mathrm{cfu} / \mathrm{mL}$ dan kontrol (tanpa inokulasi suspensi isolat bakteri penghambat). Pengamatan dilakukan terhadap mortalitas larva setelah 24 jam.

\section{Uji Pemanfaatan Bakteri untuk Meng- hambat Perkembangan $V$. harveyi pada Pemeliharaan Larva Udang Windu (P. monodon)}

Isolat yang mempunyai daya hambat terbaik terhadap perkembangan $V$. harveyi pada media MA diuji kemampuannya dalam menekan populasi $V$. harveyi. Penelitian ini dilakukan dengan rancangan acak lengkap dengan perlakuan tiga isolat bakteri penghambat GSB95030, GSB-95033 dan GSB-95040 dan masingmasing perlakuan tiga ulangan. Ke dalam 12 botol kaca yang berisi dua liter air laut yang sudah disterilkan dengan otoklaf pada suhu $121^{\circ} \mathrm{C}$ selama 15 menit, dimasukkan hewan uji (100 ekor larva udang windu stadia nauplius-6) yang diperoleh dari panti benih komersial di Banyuwangi, Jawa Timur. Kemudian ke dalam botol kaca diinokulasikan suspensi $V$. harveyi pada kepadatan $10^{7}$ pada percobaan I; $10^{6}$ pada percobaan II; dan $10^{6} \mathrm{cfu} / \mathrm{mL}$ pada percobaan III. Ke dalam sembilan botol yang dipilih secara acak selanjutnya diinokulasikan lagi suspensi tiga isolat bakteri yang berdaya hambat terbaik pada kepadatan $10^{8} \mathrm{cfu} / \mathrm{mL}$. Tiga botol lainnya dipakai sebagai kontrol (tanpa diinokulasi dengan suspensi isolat bakteri penghambat). Pengamatan dilakukan terhadap kepadatan $V$. harveyi pada media pemeliharaan dan sintasan larva udang. Percobaan I dilakukan sampai stadia zoea-1. percobaan II sampai stadia mysis-1 sedang percobaan III berlangsung sampai stadia mysis- 2 .

\section{HASIL DAN PEMBAHASAN}

\section{Isolasi}

\section{a. Isolat Bakteri Penghambat}

Hasil isolasi bakteri dari air laut, air tambak, air pemeliharaan larva dan dari tubuh udang yang berasal dari Jawa Timur dan Bali telah diisolasi 125 isolat bakteri penghambat, dengan karakter koloni mempunyai pigmen kuning, merah, jingga, hitam dan abu-abu pada media MA dan berwarna kuning serta hijau pada media TCBSA.

\section{b. Isolat Vibrio harveyi}

Isolat bakteri kunang-kunang $V$. harveyi diisolasi dari air pemeliharaan larva udang windu di panti benih komersial di Banyuwangi, Jawa Timur. Karakter bakteri $V$. harveyi di antaranya adalah dapat tumbuh pada suhu $20-35^{\circ} \mathrm{C}$, mampu mensintesis D-mannose, selobiose, tetapi tidak dapat mensintesis sukrose sehingga koloninya berwarna hijau dan bercahaya pada media TCBSA (Gambar 1a). Uji karakteristik dari isolat bakteri $V$. harveyi selengkapnya dapat dilihat pada Tabel 1 yang mempunyai kesamaan dengan karakter $V$. harveyi menurut Baumann et al. (1984).

Uji Daya Hambat Bakteri terhadap Perkembangan $V$. harveyi pada Media MA

Seratus dua puluh lima isolat bakteri di uji daya hambatnya terhadap perkembangan $V$. harveyi pada media MA. Dari hasil percobaan ini diperoleh 15 isolat bakteri yang mempunyai daya hambat terhadap perkembangan $V$. harveyi. Dari 15 isolat tersebut dipilih tiga isolat yang mampu menghambat total perkembangan $V$. harveyi, yang ditunjukkan oleh tidak adanya sama sekali pertumbuhan $V$. harveyi setelah 144 jam inkubasi. Pada kontrol terlihat perkembangan $V$. harveyi $0,45 \mathrm{~cm}$ untuk $24 \mathrm{jam}, 1,32 \mathrm{~cm}$ untuk 72 jam dan 1,96 cm untuk 144 jam. Karena itu 
ketiga isolat tersebut dipilih sebagai bakteri penghambat pada tahap penelitian selanjutnya.
Data hasil uji daya hambat tersebut disajikan pada Tabel 2.

Tabel 1. Karakteristik $V$. harveyi yang diisolasi dari air pemeliharan larva udang windu dibandingkan dengan $V$. harveyi menurut Baumann et al. (1984).

Table 1. Characteristics of $V$. harveyi isolated from larvae rearing water of $P$. monodon in comparison to V. harveyi according to Baumann et al. (1984).

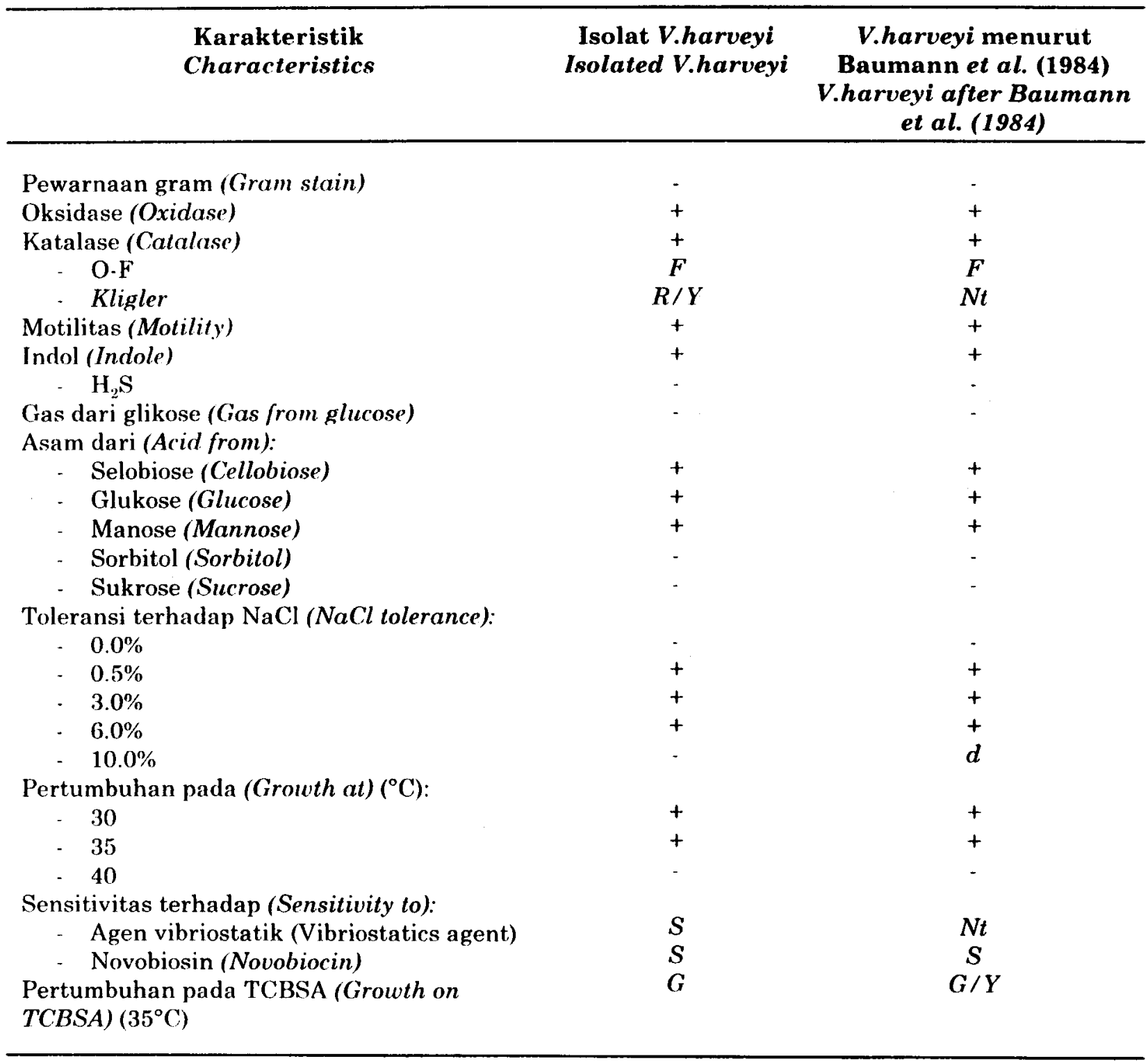

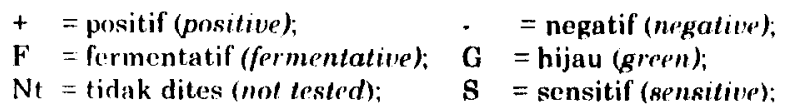

$\mathrm{d}=$ perbedaan reaksi (different reaction):

$\mathrm{Y}=\mathrm{kuning}$ (yellow)

$\mathbf{R}=\operatorname{merah}($ red $)$ 
Tabel 2. Uji daya hambat 15 isolat bakteri terhadap perkembangan $V$. harveyi pada media MA. Table 2. Inhibitory tests of 15 isolates of bacteria on the growth of V. harveyi on MA medium.

\begin{tabular}{|c|c|c|c|}
\hline \multirow{3}{*}{$\begin{array}{l}\text { Perlakuan } \\
\text { Treatment }\end{array}$} & \multicolumn{3}{|c|}{$\begin{array}{c}\text { Waktu pra-inkubasi (jam) } \\
\text { Pre-incubation time (hours) }\end{array}$} \\
\hline & 24 & 72 & 144 \\
\hline & \multicolumn{3}{|c|}{$\begin{array}{c}\text { Lebar koloni (Colony width) } \\
(\mathrm{cm})\end{array}$} \\
\hline GSB-95001 & 0.05 & 0.05 & 0.05 \\
\hline GSB-95006 & 0.10 & 0.10 & 0.10 \\
\hline GSB-95017 & 0.10 & 0.10 & 0.10 \\
\hline GSB-95030 & 0.00 * & 0.00 * & 0.00 * \\
\hline GSB-95031 & 0.10 & 0.10 & 0.10 \\
\hline GSB-95032 & 0.10 & 0.10 & 0.10 \\
\hline GSB-95033 & 0.00 * & 0.00 * & 0.00 * \\
\hline GSB-95039 & 0.10 & 0.05 & 0.05 \\
\hline GSB-95040 & 0.00 * & 0.00 * & 0.00 * \\
\hline GSB-95045 & 0.05 & 0.10 & 0.10 \\
\hline GSB-95046 & 0.10 & 0.10 & 0.10 \\
\hline GSB-95071 & 0.05 & 0.05 & 0.10 \\
\hline GSB-95098 & 0.10 & 0.05 & 0.10 \\
\hline GSB-95106 & 0.05 & 0.05 & 0.10 \\
\hline GSB-95125 & 0.05 & 0.05 & 0.05 \\
\hline Kontrol (Control) & 0.45 & 1.32 & 1.96 \\
\hline
\end{tabular}

* $=V$. harveyi tidak tambah (V. harveyi did not grow)

Uji Patogenisitas Isolat Bakteri Penghambat terhadap Larva Udang Windu $(P$. monodon)

Terhadap isolat bakteri yang mempunyai daya hambat terbaik terhadap perkembangan $V$. harveyi dilakukan uji patogenisitas pada larva udang windu stadia zoea-1. Dari penelitian tersebut diperoleh data bahwa pemberian suspensi masing-masing isolat bakteri pada kepadatan $10^{5}$; $10^{6} ; 10^{7} ; 10^{8} \mathrm{cfu} / \mathrm{mL}$ selama 24 jam tidak mengakibatkan mortalitas yang berarti bagi larva uji (Tabel 3).

Dari hasil uji di atas terlihat bahwa ketiga isolat bakteri penghambat tersebut tidak bersifat patogen terhadap larva udang uji, di mana antar perlakuan dengan kontrol tidak memberikan perbedaan yang nyata $(\mathrm{P}>0,05)$. Berdasarkan hal ini maka dilakukan percobaan pemanfaatan ketiga isolat bakteri penghambat tersebut dalam pemeliharaan larva udang windu.
Uji Pemanfaatan Isolat Bakteri Penghambat untuk Menekan Perkembangan V. harveyi pada Pemeliharaan Larva Udang Windu

Hasil pengamatan menunjukkan bahwa selama delapan jam setelah inokulasi suspensi bakteri $V$. harveyi pada air pemeliharaan larva, terjadi akumulasi bakteri tersebut dalam tubuh larva yang ditandai dengan bercahayanya larva pada kondisi gelap. Hal ini merupakan tanda awal dari sifat patogennya $V$. harveyi. Zoea adalah stadium yang paling rawan terhadap infeksi $V$. harveyi, karena pada stadia ini larva sudah mempunyai saluran pencernaan dan mulai aktif makan dengan cara menyaring air (Zafran dan Roza, 1992). Pada larva yang terinfeksi $V$. harveyi terjadi penyusutan hepatopankreas dan perubahan warna menjadi coklat kehitaman. Roza dan Zafran (1992) serta Roza (1993) menemukan bahwa secara histopatologi hepatopankreas sudah rusak dan dipenuhi oleh 
bakteri gram-negatif yang berbentuk batang sehingga tidak dapat berfungsi normal, baik dalam penyerapan nutrien maupun dalam produksi enzim untuk pencernaan.

\section{Percobaan I}

Pada percobaan ini kepadatan bakteri $V$. harveyi yang diinokulasikan adalah $10^{7} \mathrm{cfu} / \mathrm{mL}$, dan suspensi isolat bakteri penghambat diinokulasikan pada kepadatan $10^{8} \mathrm{cfu} / \mathrm{mL}$. Ternyata setelah 24 jam pengamatan hampir semua larva pada setiap perlakuan mengalami kematian akibat keganasan bakteri $V$. harveyi. Pada penelitian ini kepadatan $V$. harveyi yang diinokulasikan terlalu banyak sehingga isolat bakteri penghambat tidak mampu menekan perkembangan populasi bakteri patogen tersebut, akibatnya setelah 24 jam perlakuan terpaksa dilakukan pemanenan larva udang windu (Tabel 4).

\section{Percobaan II}

Pada percobaan II kepadatan suspensi bakteri $V$. harveyi yang diinokulasikan adalah $10^{6} \mathrm{cfu} /$ $\mathrm{mL}$, sedangkan suspensi isolat bakteri penghambat yang diinokulasikan adalah $10^{8} \mathrm{cfu} / \mathrm{mL}$. Ternyata diperoleh hasil yang baik, di mana kepadatan $V$. harveyi dan sintasan larva pada penginokulasian suspensi isolat bakteri GSB95030 berbeda nyata $(\mathrm{P}<0,05)$ terhadap kontrol maupun dengan isolat GSB-95033 dan GSB95040. Hasil tersebut menunjukkan bahwa isolat bakteri GSB-95030 mempunyai kemampuan paling tinggi untuk menekan perkembangan $V$. harveyi dalam media pemeliharaan larva udang windu $\left(1,1 \times 10^{4} \mathrm{cfu} / \mathrm{mL}\right)$ dan memberikan sintasan yang tinggi (77,3\%). Pada perlakuan pemberian isolat bakteri GSB-95033 dengan kepadatan bakteri $V$. harveyi 8,4 × $10^{4} \mathrm{cfu} / \mathrm{mL}$ dihasilkan sintasan $34,0 \%$. Pemberian suspensi isolat bakteri GSB-95040 pada kepadatan $V$. harveyi $12,4 \times 10^{4}$ cfu/mL tercatat sintasan sebesar $27,7 \%$. Pada kontrol ternyata populasi $V$. harveyi jauh lebih tinggi yakni $22,5 \times 10^{4} \mathrm{cfu} / \mathrm{mL}$ dengan sintasan yang relatif lebih rendah (17,3\%). Hasil lengkap perlakuan masing-masing isolat bakteri disajikan pada Tabel 4.

\section{Percobaan III}

Pada percobaan III ini kepadatan suspensi $V$. harveyi yang diinokulasikan adalah $10^{6} \mathrm{cfu} / \mathrm{mL}$, dan kepadatan isolat bakteri yang diinokulasikan adalah $10^{8} \mathrm{cfu} / \mathrm{mL}$. Hasil penelitian menunjukkan bahwa secara statistik pada perlakuan isolat bakteri GSB-95030, GSB-95033, dan GSB-95040 memperlihatkan kepadatan bakteri $V$. harveyi yang berbeda nyata $(\mathrm{P}<0,05)$ dibandingkan dengan kontrol (tanpa inokulasi suspensi isolat bakteri penghambat). Sintasan yang paling tinggi diperoleh pada perlakuan isolat GSB-95030 dan berbeda nyata $(\mathrm{P}<0,05)$ dibandingkan pada perlakuan isolat bakteri GSB-95033, GSB-95040 dan kontrol. Data lengkap terlihat pada Tabel 4.

Tabel 3. Patogenisitas tiga isolat bakteri terhadap larva udang windu ( $P$. monodon) selama 24 jam pengamatan.

Table 3. Pathogenicity tests of three isolates of bacteria to the larvae of P. monodon at 24 hours exposure time.

\begin{tabular}{|c|c|c|c|c|c|}
\hline \multirow[t]{2}{*}{$\begin{array}{l}\text { Perlakuan } \\
\text { Treatment }\end{array}$} & \multicolumn{5}{|c|}{$\begin{array}{c}\text { Sintasan }(\%) \text { pada masing-masing kepadatan bakteri }(\mathrm{cfu} / \mathrm{mL}) \\
\text { Survival rate }(\%) \text { at respective bacteria density }(\mathrm{cfu} / \mathrm{mL})^{*}\end{array}$} \\
\hline & 0 & $10^{5}$ & $10^{6}$ & $10^{7}$ & $10^{8}$ \\
\hline GSB-95030 & $100.0^{\mathrm{a}}$ & $99.0^{a}$ & $99.0^{\mathrm{a}}$ & $99.0^{a}$ & $98.0^{a}$ \\
\hline GSB-95033 & $99.0^{\text {a }}$ & $99.0^{a}$ & $98.0^{\text {ว }}$ & $99.0^{\mathrm{a}}$ & $99.0^{\text {a }}$ \\
\hline GSB-95040 & $99.0^{\mathrm{a}}$ & $99.0^{\circ}$ & $98.0^{\text {a }}$ & $97.0^{a}$ & $97.0^{\text {a }}$ \\
\hline
\end{tabular}

* Angka dalam kolom yang diikuti huruf superskrip yang sama menunjukkan tidak berbeda nyata $(P>0,05)$

* Values in columns with the same superscript indicated not significantly different $(P>0.05)$ 


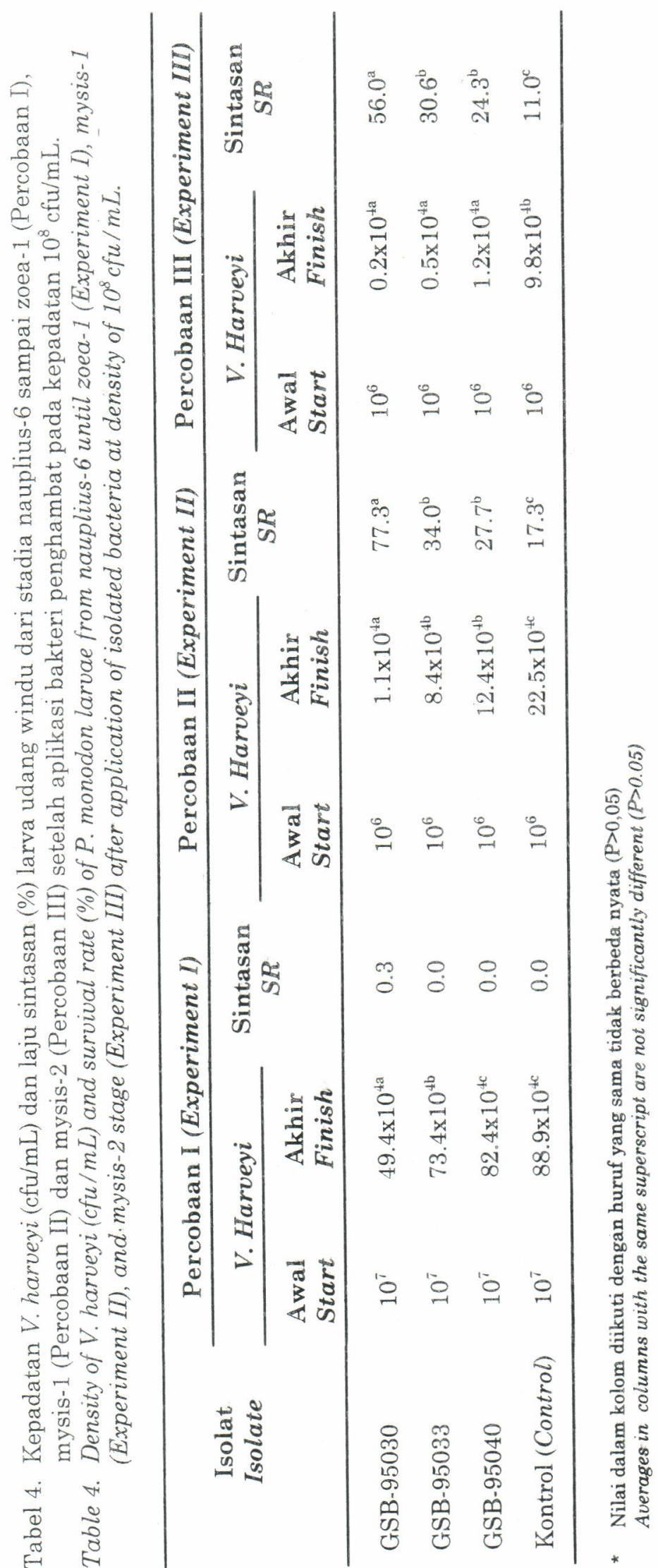


Dari hasil penelitian diketahui bahwa tiga isolat bakteri penghambat yang diisolasi dari air pemeliharaan larva udang windu di panti benih komersial di Banyuwangi, Jawa Timur dapat dimanfaatkan sebagai bakteri penghambat perkembangan $V$. harveyi dalam air pemeliharaan. Diduga bahwa isolat bakteri tersebut mempunyai zat penghambat yang bersifat mematikan $V$. harveyi (bakterisida). Karakter isolat bakteri GSB-95030 di antaranya adalah gram negatif. tumbuh pada temperatur $20-42^{\circ} \mathrm{C}$, koloninya melayang pada media MA/TSA, dapat mensintesis sukrose sehingga koloninya berwarna kuning pada media TCBSA tetapi tidak memproduksi cahaya (Gambar 1b). Isolat bakteri penghambat GSB-95030 ini karakternya sama dengan isolat bakteri yang digunakan pada penelitian Garriques \& Arevalo (1995), di mana bakteri tersebut dapat meningkatkan pertumbuhan dan sintasan larva Penaeus vannamei secara probiotik. Sedangkan isolat bakteri penghambat GSB-95033 dan ( lain mempunyai pigmen kuning (Gambar 2, a dan b), gram negatif, indol positif, motil, oksidase dan katalase positif, tumbuh pada temperatur 20 . $35^{\circ} \mathrm{C}$, dan dapat mensintesis glukose. Ternyata, sifat-sifat tersebut memiliki kesamaan karakter dengan dua strain bakteri hasil penelitian Austin (1988) yakni koloni mempunyai pigmen kuning, gram negatif, motil, tumbuh pada temperatur 20 . $35^{\circ} \mathrm{C}$, resisten terhadap agen vibriostatik $(0 / 129)$, katalase dan indol posititif, satu di antaranya dapat memproduksi $\mathrm{H}_{2} \mathrm{~S}$.

Penelitian ini menunjukkan bahwa populasi $V$. harveyi akan menurun sejalan dengan keberadaan bakteri penghambat pada media pemeliharaan larva udang windu, di mana akan terjadi persaingan antara isolat bakteri penghambat dengan $V$. harveyi. Hal ini juga diperkuat oleh Garriques dan Arevalo (1995) bahwa peranan bakteri sebagai pengontrol secara biologis adalah dengan terjadinya persaingan maupun memproduksi substansi yang dapat menghambat perkembangan bakteri patogen.

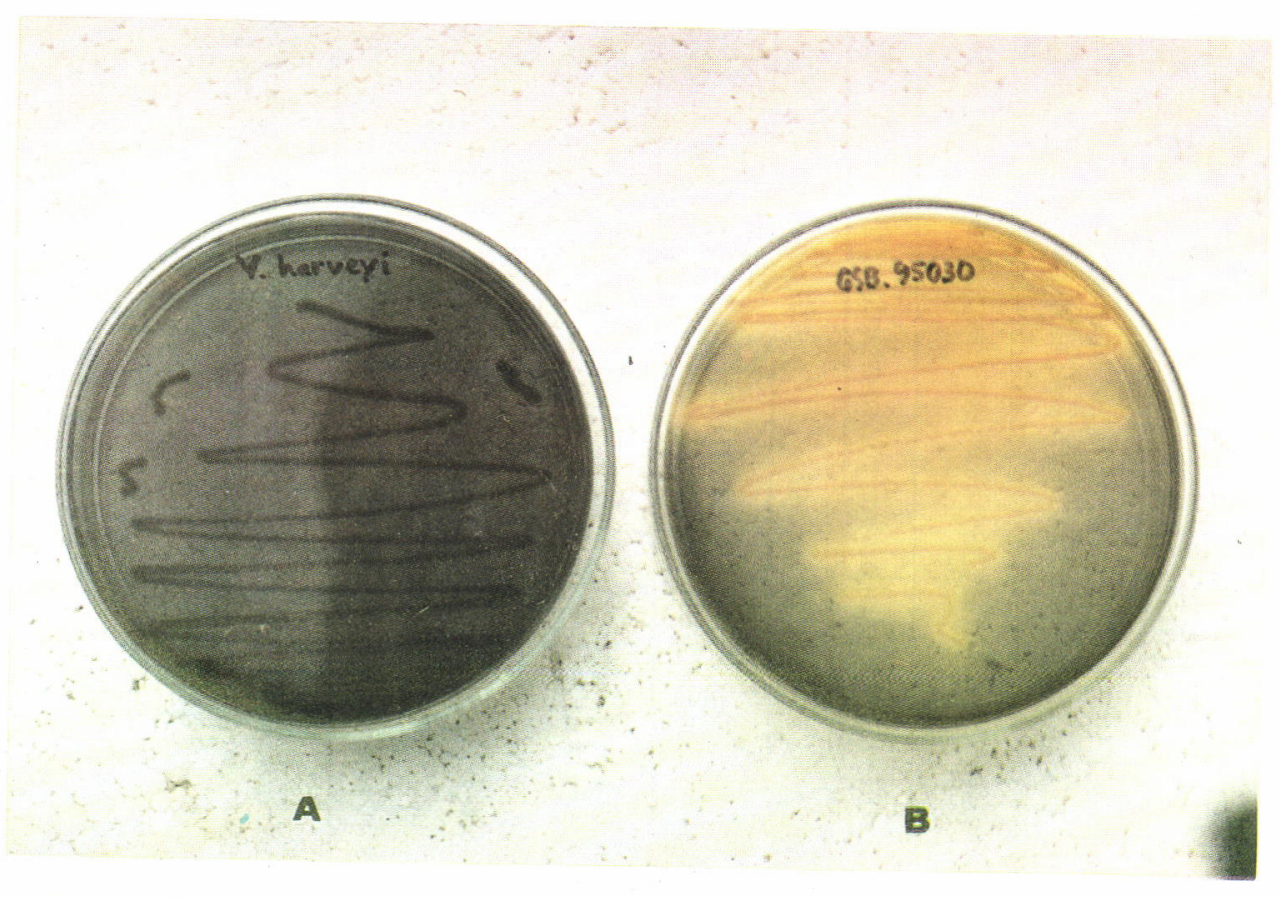

Gambar 1. Koloni V. harveyi (A) dan bakteri penghambat GSB-95030 (B) pada media TCBSA.

Figure 1. Colony of V.harveyi (A) and GSB-95030 (B) on TCBSA medium. 


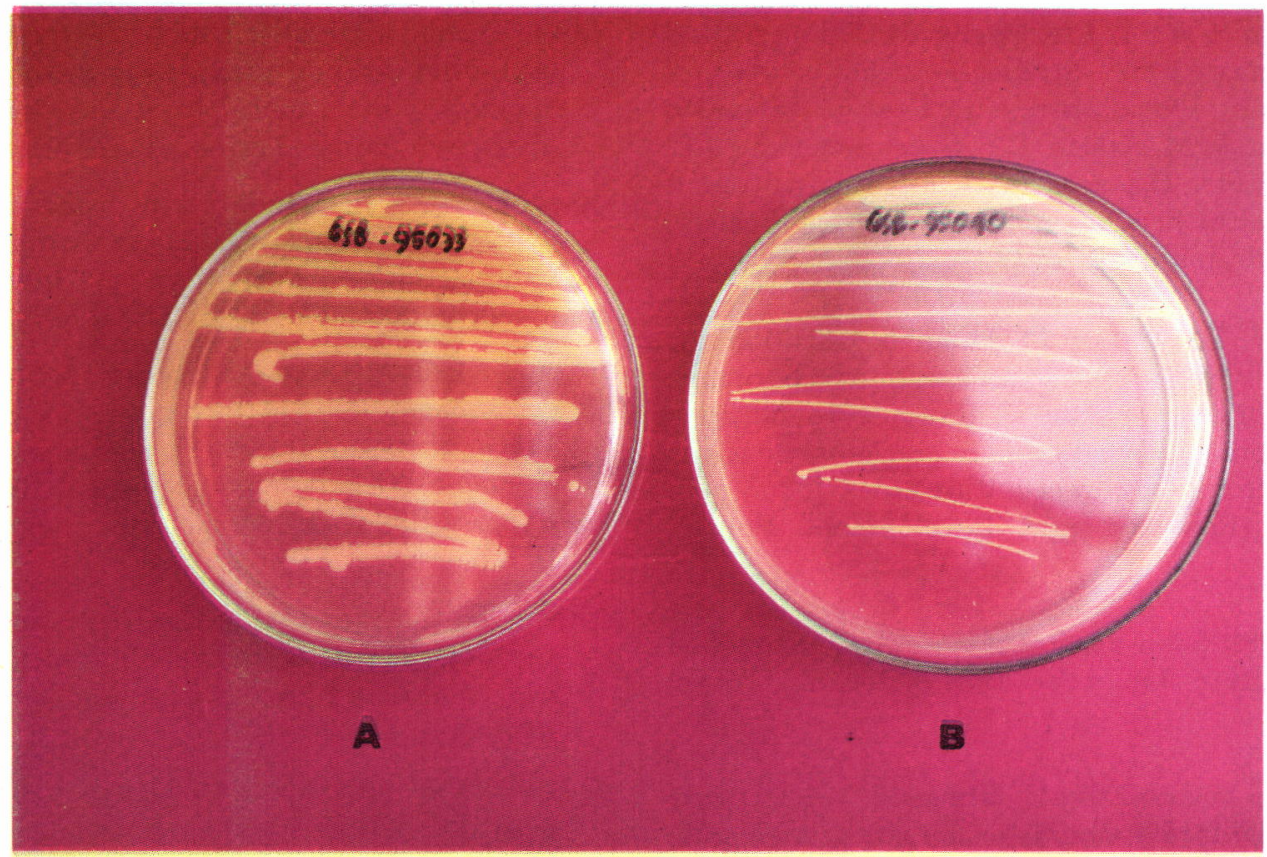

Gambar 2. Koloni bakteri penghambat GSB-95033 (A) dan GSB-95040 (B) pada media MA.

Figure 2. Colony of GSB-95033 (A) and GSB-95040 (B) on MA medium.

Berdasarkan hasil penelitian di atas diketahui bahwa di antara ketiga isolat bakteri penghambat GSB-95030, GSB-95033 dan GSB-95040, ternyata hanya dua isolat yang mempunyai kemampuan terbaik dalam menekan perkembangan V.harveyi. Maka untuk uji selanjutnya digunakan isolat bakteri penghambat GSB-95030 dan GSB-95033 karena dari uji karakterisasi pendahuluan isolat bakteri penghambat GSB-95040 memperlihatkan karakter yang sama dengan isolat bakteri penghambat GSB-95033.

\section{KESIMPULAN}

Dari 125 isolat bakteri penghambat yang diuji, terdapat tiga isolat yaitu GSB-95030, GSB-95033, dan GSB-95040 yang mempunyai daya hambat lebih tinggi terhadap $V$. harveyi dibanding isolat bakteri lain. Ketiga isolat bakteri tersebut dapat menekan perkembangan $V$. harveyi sampai batas aman bagi larva udang windu yakni di bawah $8,35 \times 10^{4} \mathrm{cfu} / \mathrm{mL}$.

\section{SARAN}

Untuk uji aplikasi disarankan hanya menggunakan dua isolat bakteri penghambat GSB-
95030 dan GSB-95033 karena isolat bakteri penghambat GSB-95040 memiliki karakter yang sama dengan isolat bakteri penghambat GSB95033, sehingga diketahui kepadatan isolat bakteri penghambat yang efektif dalam menekan perkembangan vibrio bercahaya.

\section{DAFTAR PUSTAKA}

Austin, B, 1988. Marine microbiology. Cambridge University Press, England. 222 pp.

Baticados, M.C.L. and J.D. Paclibare, 1992. The use of chemotherapeutic agent in aquaculture in the Philippines. In M. Shariff, R.P. Subasinghe, and J.R. Arthur (Eds.), Diseases in Asian Aquaculture I. Fish Health Section, Asian Fisheries Society, Manila, Philippines: 531-546.

Baumann, P., A.L. Furnis, and J.V. Lee, 1984. Facultatively anaerobic Gram-negative rods. In Noel R. Krieg (Eds.) Bergeys Manual of Systematic - Bacteriology, Vol. 1. Williams \& Wilkins, Baltimore, USA: 518-538.

Garriques, D,. and G. Arevalo. 1995. An evaluation of the production and use of alive bacterial isolate to manipulate the microbial flora in the commercial production of Penaeus vannamei post larvae in Equador. p.53-59. Granjas Marinas El Rosario S.A., Guayaquil, Equador. 
Lavilla-Pitogo, C.R., L.J. Albright, M.G. Paner, and N.A. Sunaz, 1992. Studies on the sources of luminescent Vibrio harveyi in Penaeus monodon hatcheries. In M. Shariff, R.P. Subasinghe and J.R. arthur (Eds.). Diseases in Asian Aquaculture I. Fish Health Section, Asian Fisheries Society, Manila, Philippines: 157-164.

Lightner, D.V, T.A. Bell, R.M. Redman, L.L. Mohney, J.M. Natividad, A. Rukyani, and A. Poernomo, 1990. Indonesian marine shrimp culture industry: observations, constraints, and recommendations resulting from a survey of culture areas. Indonesian Fisheries Research and Development Project, USAID.

Maeda, M, 1989. Some aspects of biocontrolling method in aquaculture. Japan Soc. Mar. Biotechnol, Tokyo: 395-397

Maeda, M., K. Nogami, and N. Ishibashi. 1992. Utility of microbial food assemblages for culturing a crab, Portunus trituberculatus. Bull. Natl. Res. Inst. of Aquaculture 21:31-38.

Maeda, M, 1994. Biocontrol of the larvae rearing biotope in aquaculture. Bull. Natl. Res. Inst. Aquaculture, Suppl. 1:71-74
Roza, D. dan Zafran, 1992. Karakteristik beberapa isolat bakteri bercahaya yang diisolasi dari larva udang windu, Penaeus monodon. Jurnal Penelitian Budidaya Pantai, Maros: 8(3):93-98.

Roza, D, 1993. Pengendalian populasi bakteri Vibrio harveyi di hatchery udang windu. Prosiding Simposium Perikanan Indonesia I, Puslitbangkan/No. 18. Jakarta: 89-92.

Roza, D, 1995. Uji coba penggunaan Flavobacterium $s p$. sebagai kontrol biologi untuk pengendalian Vibrio harveyi di hatchery udang windu (Penaeus monodon). Disajikan pada Seminar Ilmiah XIV dan Kongres Biologi XI, Universitas Indonesia, Depok: 10 hal.

Roza, D., Zafran dan I. Koesharyani. 1997. Studi tentang organisme penyebab bercak merah pada bak pemeliharaan larva udang windu (Penaeus monodon). (In Press).

Zafran dan D. Roza, 1992. Upaya penanggulangan penyakit bakteri bercahaya pada larva udang windu, Penaeus monodon. Prosiding Temu Karya Ilmiah Puslitbangkan/No.34:48-51.

Zafran dan D. Roza, 1993. Teknik penanggulangan penyakit udang menyala di hatcheri melalui pengendalian populasi bakteri. Jurnal Penelitian Budidaya Pantai 9(2):127-132. 